\title{
LINKAGE OF LEISURE WITH REMOTE WORK AND DIGITAL NOMADISM IN TOURIST ACCOMMODATION FACILITIES
}

\author{
Tamara Floričić \\ Nadia Pavia
}

https://doi.org//10.20867/tosee.06.17

\begin{abstract}
Purpose - Tourism accommodation facilities with workstations for remote work enable stays and business activities. Different contexts of modern tourism and the hospitality industry affect the development of this innovative form of accommodation offer supported by technology, often called "workspitality". The presented concept is the subject of the research which the authors are conducting with the aim to detect the preparedness of the hospitality industry, namely small private entrepreneurs, to respond to the challenges of competitiveness.

Methodology - The methodology includes scientific analyses of the potential for affirmation of innovative accommodation concepts "workspitality" tourism product. The research design included metasearch as well as original scientific processing of data obtained through a structured questionnaire. Methods include statistics as well as qualitative methods, including focus groups and creative thinking techniques and impact the formation of conclusions which point to new scientific knowledge.

Findings - The findings point to the conclusion that supply providers should learn about new competitiveness potential, so the education relating to offer organisation and investments could provide solutions to the quality organisation of the specific offer.

Contribution - The paper represents a valuable contribution to an understanding of the organisation and innovation of receptive offer in tourist destinations. The research results, as well as the obtained knowledge, could affect the perception of the decision makers i.e., accommodation owners and managers, about the importance of adjustment of existing structures and facility equipment in accordance with demand preferences. The adjustment to the new demand preferences targets competitive advantage and business results. The research results reflect on the formation of scientific knowledge in the area of organisation of accommodation offer, as well as on the consideration and identification of its key elements.
\end{abstract}

Keywords: remote work, holiday rentals, serviced apartments, digital nomads, technology, competitiveness.

\section{INTRODUCTION}

Over the last year, remote working has become the most prevalent way of working, especially for office jobs. Furthermore, the tourism industry has taken a toll with the COVID-19 pandemic. We can notice a need for employees to change and vary their working environments and for hotels and tourism infrastructures to restore their financial situations. 
ToSEE - Tourism in Southern and Eastern Europe, Vol. 6, pp. 247-268, 2021.

T. Floričić, N. Pavia: LINKAGE OF LEISURE WITH REMOTE WORK AND DIGITAL NOMADISM ...

For these reasons more and more, remote working spaces are being developed. In this paper, we have analysed different infrastructures and their specificities towards this new working lifestyle.

However, with the mentioned restrictions on travel (covid testing, quarantine...) the behaviour of travellers has changed a lot and they want to stay longer at their holiday/workplace. At this point of recognition of this market trend, new terms of the innovative concept have emerged: workspitality, bleisure, staycation. All of them fulfil the needs of new demand and travellers who combine work with vacation dependent on Internet technology. What appeals to travellers is not just staying and working from somewhere new and exciting, but the convenient package of accommodation, workspace and community in one place (Digiday 2021).

The "digital nomad" can be self-employed (freelance, entrepreneur...), or employed. They can carry out their activity remotely, thanks to the Internet, which connects them to all the people related to their work. They will therefore travel to a different country from the home country of their companies and work abroad remotely.

Moreover, with the COVID-19 pandemic, remote working started to be widely implemented and advised by the government; a lot of companies started using new methods of managing their teams related to the impact of the worldwide pandemic that we are currently living in. Many different business technology websites such as https://www.cvent.com/ (organisation of on line business meetings and hybrid events), https://zoom.us/ (platform that enables "work from anywhere") as well as hospitality offer providers (booking.com, https://workanywhere.marriott.com/play-pass, https://world.hyatt.com/) has identified this new kind of workers and they started to offer a new kind of life and business environment to them.

There are not many scientific researches on this quite innovative topic. This pioneering research brings novelty to the scientific consideration of remote work hospitality accommodation facilities with the main aim to expand the knowledge and to create a platform of recommendation in order to bridge the gap between science and practical business. The paper is divided into four chapters; firstly, the theory of digital nomadism and remote work is presented, along with the important segment of SME and alternative accommodation structures (homestays, villas, holiday rentals, agritourism, family hotels) where the trend of remote work, supported by physical distancing and affirmed privacy, should be implemented in accommodation offer. The second chapter presents the methodology and the research design, followed by the research results and discussion presented in the third chapter. The paper concludes with final remarks and recommendations.

In consideration of the topic area of the paper, the following problem question is defined: in what measure are the SME and micro-entrepreneurship offer providers prepared to adapt their accommodation structures to the requirements of the remote work segment, digital nomads within the system of the workspitality concept? The research question, tested by the offer stakeholders' attitudes, contribute to the answer to the problem question, $R Q 1$ : the workspitality concept can impact the extension of the tourist season 
ToSEE - Tourism in Southern and Eastern Europe, Vol. 6, pp. 247-268, 2021.

T. Floričić, N. Pavia: LINKAGE OF LEISURE WITH REMOTE WORK AND DIGITAL NOMADISM ...

and $R Q 2:$ in order to reach the specific guest segment, specialised portals are important, through which a targeted promotion and distribution are realised.

\section{NEW CONCEPT OF ACCOMMODATION OFFER - REMOTE WORK, DIGITAL NOMADS AND TOURISM}

The paper explores a mobile way of living, preferences of the demand of digital nomads and remote work, a fast-spreading group of individuals who work while travelling and travel while working. Social and business emergence of digital nomadism and remote work has been encouraged by important technological changes, such as growing mobility and development of new technologies in individuals' everyday lives. This opens the possibility of flexible and spontaneous employment, opens the questions of visas for digital nomads and formation of communities, digital nomad villages (Bala 2021). The phenomenon of digital nomadism and remote work is still young and unexplored. New literature on that topic is often fragmented, i.e., information is scattered throughout different disciplines, be it economics, technology, sociology or globalisation.

Apart from health and safety, companies decide to organise remote work also for reasons of the savings that can be made. The development of the creative mindset, where digital nomads and remote workers meet each other in a diffused and new random environment, contributes to the creation of new ideas which, in turn, improve the business and open new developmental perspectives (Vagena 2021). On the other hand, according to Forbes magazine (2021), Neetbeez platform (2021) and Electric.ai (2020) organisation of remote work of a larger number of people, performance measurement and IT support can prove to be very expensive, so ICT companies recognise the marketing potential and make agreements with employers. Efforts of companies like Zoom are identified in trying to convince workers and company directors that work is no longer a task that has to be performed a fix office space surrounded by colleagues.

Digital nomadism is a deeper trend, conditioned by work flexibility and mobility, when the $21^{\text {st }}$ century workers follow dynamic trends and, with strong technology support, decide to work for themselves, to establish Internet companies or to remotely work for companies that allow it, giving their employees the opportunity to become independent of a fixed workplace. Digital nomads represent a population of business, mostly younger, people, managers, employees, entrepreneurs who are "independent of location". They can work from any place with the essential connection with technology and Internet (Richter and Richter 2020). The business concept is not based on property and a fixed office but, through their activities, they invest in experiences and not in objects (Thompson 2018). This makes them a growing and important segment for the tourism industry, and tourism operators and governments adapt their offers and visa programmes in order to attract the largest possible number of mobile workers (Mueller 2016).

The main characteristics of digital nomadism are:

- independent, remote workers who combine travel with flexible work obligations

- an increased share of travel operators and hoteliers introduce new services, focused on this segment 
ToSEE - Tourism in Southern and Eastern Europe, Vol. 6, pp. 247-268, 2021.

T. Floričić, N. Pavia: LINKAGE OF LEISURE WITH REMOTE WORK AND DIGITAL NOMADISM ...

- co-working offices and business centres in modern hospitality business

- office facilities in hotel rooms, with services of a business centre within the hotel system and offer.

Considered from the aspect of tourist expenditure, digital nomads are not seasonal travellers, and they tend to choose locations off the beaten track, often dislocated from main tourist attractions, point out Andres et al. (2019) and they add that digital nomads aim to establish their own base, both in less expensive and in trendy destinations, provided they can be equipped with a powerful digital infrastructure. According to the World Youth and Student Event (WISE) Travel Confederation report, digital nomads' age has been identified to be between 26 and 29 years of age, and over $70 \%$ of them have a certain degree of higher education.

In the context of youth tourism, Greg Richards (2020a) and WYSE point out that a rapid growth of this segment is encouraged by inexpensive travel possibilities, an increase in cooperative free work and a multitude of services and tools which, including mobile appliances, also facilitate areas for cooperation (Richards 2020b).

Even before the COVID-19 pandemic, there existed pronounced trends towards remote working, also among those who had full time employment in an organisation. The pandemic was the main accelerator of this trend, given that it affected the organisation of work from home and the transformation of business processes and procedures. From paperwork and personal presence and communication with clients, numerous jobs and professions have turned to digital where, from remote destinations, workers who work from home realise better efficiency and productivity, unrelated to working hours and location. Richards predicts expectations by which American office areas will be reduced this year by $17 \%$ and that eight out of ten companies intend to continue allowing and encouraging remote working by their employees (partly, if not possible entirely). The majority of workers $(71 \%)$ claim that they would wish to keep the flexibility of remote work also after the pandemic has abated, in future perspectives.

\subsection{Aspects of remote work - new role of accommodation facilities}

The COVID-19 pandemic has sped work and office life, becoming a powerful catalyst for changes in the workplace. Within several weeks, the Coronavirus crisis forced a large part of the global workforce to accept remote work (Hermann and Cody 2021). This sudden and extreme shift has raised many questions about the sustainability of this new method of work, especially regarding workplace productivity. More specifically, it has made many people ask questions about the role and purpose of physical offices in the future. The research by the consulting firm JLL (2020a), conducted on over 3,000 employees from different industries around the world, shows that physical offices will continue being critical in ensuring organisational performance in the post-pandemic world. Also, it stresses the imperative for optimisation of remote workers' experiences and improvement of human performances and productivity in future workplaces.

The prerequisite for the development of distance working and remote working is the development of modern technologies and platforms for online communication, video 
ToSEE - Tourism in Southern and Eastern Europe, Vol. 6, pp. 247-268, 2021.

T. Floričić, N. Pavia: LINKAGE OF LEISURE WITH REMOTE WORK AND DIGITAL NOMADISM ...

streaming and content downloading on and from cloud platforms. Services and digital platforms, such as Vonage, Zoom, Google Meets or Teams, develop disruptive technologies which change the perception of jobs, their descriptions and traditional procedures, and the changes occur overnight. Due to the crisis developments, numerous public and private sector business subjects have, within a short time, overcome the perception barriers of their employees and adopted technological tools and services in their everyday business activities and in their private lives. The adopted business models and advantages emanating from them are becoming a "new normal" and form a platform for consideration of the concepts and tourism of the future. De Jong and Lee (2020) emphasise that the development of the companies based on knowledge is subject to:

- Talent competitiveness - offer of remote working jobs does not geographically constrain either the employer or employees and enables interconnection of the most talented workers with specific jobs and tasks. Due to savings in time and travel costs, remote working in job offers represents a competitive advantage in relation to office work.

- Savings on costs - in the majority of companies - both small and large ones, business premises are often the second largest cost, after payroll calculations. An opportunity to eliminate or reduce this cost category, without any effect on productivity, is the business goal and, therefore, the companies will use distant working in order to re-examine the productivity rate in relation to cost-effectiveness, and to employ more talents who will, in turn, develop more products, bring a bigger income or create larger clients.

- Environmental, social and managerial priorities - sustainability and diversity - have become extremely high priorities in many companies, as well as for investors who support them. The ability to reduce $\mathrm{CO} 2$ emissions by reducing daily car travel represents an advantage which managerial shareholders include in CSR (Corporate Social Responsibility).

- Employees' health - remote working facilitates a flexible work schedule which, in turn, enables a better balance with family and bodily health and alleviates the moments of micro-stress which lead to poor mental health in the office. Happier employees stay and have greater work productivity and are more loyal to the firm they are working for.

- Increased productivity - the study points out that employees who work remotely spend more time working and speak more frequently. Meetings begin and end on time. Documentation and use of tools for project management are on the increase, with fewer gaps in communication, as teams adopt more asynchronous work. For larger organisations, remote working also facilitates more efficient leadership for managers, as well as a better organisation for the purposes of elimination of oversights.

The transformations due to the COVID-19 pandemic have changed the perception of safety of offices as workspaces where people often spend more than eight hours a day. The "Open office" organisational office concept is becoming a less acceptable and problematic working environment with a more demanding application of safety measures and standards. The trend of development of co-working spaces which, since 2017, expert business development companies assessed as a revolutionary organisational innovation, has changed from the perspective of business concept for digital nomads, with an annual growth of over $29 \%$ (Jll 2020b) into the concept of a declining competitiveness and demand, given the impossibility of ensuring physical distancing and a safe and healthy 
ToSEE - Tourism in Southern and Eastern Europe, Vol. 6, pp. 247-268, 2021.

T. Floričić, N. Pavia: LINKAGE OF LEISURE WITH REMOTE WORK AND DIGITAL NOMADISM ...

working environment. Namely, the development of a flexible space (flex space) included the organisation of common office spaces which are equipped with business bases like Wi-Fi and furniture and, more increasingly, also with a series of services, such as coffee bars and social events, tailored according to the users' requirements (von Zumbusch and Laličić 2020).

The synergy of spending free time and work time is becoming a new life perspective of the phenomenon of remote work and digital nomadism, stresses Orel (2020). He further claims that entrepreneurship and capitalism are fully accepted in the nomadic lifestyle; the accent is put on a holistic approach to life and acceptance of work as a mechanical activity needed for existence, but not for the purpose of existence.

Remote work enables the remote workers and digital nomads to affirm nonmaterial, intangible values of their work combined with leisure activities:

1. fluidity of work commitments - REMOTE WORK

2. workspace flexibility $-\mathrm{CO}$-WORKING

3. balance between work and holiday

4. year-round stays, unrelated to seasonal periods

5. longer stays

6. more favourable prices

7. destinations remote from big cities - "Working remotely, from a remote location" (Gupta 2021).

The synergy of remote work and tourist stay is clearly presented through contemporary terminology which, through a combination of words and abbreviations, represents an organisational concept. A more widely accepted term of bleisure defines conduct of business activities in synergy with holidays and recreation points out Kachniewska (2016). In continuation, a wide range of new words are brought into the hospitality terminology and they have found their place in common, professional and scientific use:

- Bleisure - Business + Leisure

- Officetel-Office + Hotel

- Workliday - Work + Holiday

- Workcation - Work + Vacation

- Staycation - Stay + Vacation

- Daycation - Day + Vacation

- Workspitality - Work + Hospitality

According to the research presented by the leading world hotel corporation, Marriott International, travellers who could work remotely encounter various issues that affirm the motivation and preferences for remote work and stays in hotels. The identified benefits of remote work in hotels are as follows (Marriott 2020): 
ToSEE - Tourism in Southern and Eastern Europe, Vol. 6, pp. 247-268, 2021.

T. Floričić, N. Pavia: LINKAGE OF LEISURE WITH REMOTE WORK AND DIGITAL NOMADISM ...

- Wish to break the everyday monotony.

- Non-existence of inspirative work environment and the feeling of claustrophobia in small flats.

- Absence of the limit between work and personal life, especially for families who carry out/live distant learning for children.

- Impossibility of focusing and continuity of work in important presentations, projects and meetings.

- Insufficient Wi-Fi signal.

New dynamic and fast changes in business operations, supported by modern technology, present a platform for the development of remote work and, furthermore, development of innovative hospitality (Lychy and McLeay 2018). The changes are as follows:

- Increase in remote work results in an increase in allocated teams who travel.

- Remote work does not mean exclusively work from home; the work can be done from any location.

- New models of travel and use of hospitality services with regard to mono-located firms which, up to now, have not consumed hospitality services in such a way.

- Technology and innovations.

The problem of remote working is manifested in the relationships and building of connections, given that people are social beings who pursue socialisation and who, in mutual work, develop trust, empathy and other humanising elements which they strive to achieve by means of videoconferences. Furthermore, the problem is emphasised of innovations and strategies, as well as a passive transfer of knowledge of older colleagues to the younger ones. Informal business meetings, dinners and receptions contribute to nonverbal communication and contribute to a friendly ambience which has a stimulating effect on closing of new business deals. Also, within the teams, the value of internal corporate gatherings is recognised, which enables a deeper interconnection of teams and create socalled "under the radar" relationships.

However, it is important to point out the challenges that are facing the business travel sector due to the physical and social distancing and travel restrictions. Moreover, the success of remote work, online virtual meetings and hybrid events via digital platforms that save money and time have seriously impacted the tendencies for business travel. Lubbe (2020) addresses different questions of the perspective of business trips, an industry which has, due to the COVID-19 pandemic, faced serious competitiveness challenges.

Price policy is one of the powerful tools of the struggle for competitiveness in the turbulent tourism market. In the pandemic conditions and perspectives of post-pandemic tourism, numerous hotels now offer reduced prices and other different incentives and service packages for people who are looking for longer stays with the possibility of using their rooms as an office. In the context of the problem area, the questions of new costeffectiveness are asked, given the change in the number of accommodation units. The hospitality industry experts, managers and consultants, however, are optimistic about the future of the workspitality model: "This is our first hotel partnership, but you can certainly expect many more. This simply makes too much sense and perfectly fits into the future of the business and workplace experience", claims Hodari (2020). 
ToSEE - Tourism in Southern and Eastern Europe, Vol. 6, pp. 247-268, 2021.

T. Floričić, N. Pavia: LINKAGE OF LEISURE WITH REMOTE WORK AND DIGITAL NOMADISM ...

\subsection{How to match new demand and supply in hospitality industry to the requirements of remote work concept}

Considering that remote work has become a new norm in our society, companies need to make certain changes in order to adapt to the present situation because now, more and more people are searching to stay a longer period of time in a specific tourism destination. Working from home has become an impetus for increased demand for private environments due to health and safety concerns. The new trend points to further developmental potentials of the remote work concept where, with a stable Internet, jobs can be done regardless of the geographical context.

With pricing discrimination, the innovative concept of the service can be manifested in different variants: (1) ensuring accommodation for guests who wish a day-long stay, from early morning to evening, (2) extended overnight with an early morning check-in and evening payment, or (3) a several-day long stay and a resting-place for free time.

Consumers have expressed what they consider as important when taking a hotel room for their workspace (Marriott 2020):

- fast and reliable Wi-Fi and technology

- clean and disinfected work areas

- ample table-top space with a comfortable chair and a lot of nearby plug sockets

- modern space with a view and natural light

- peace and quiet without disturbance

- access to coffee, bottled water and food

- access to hotel facilities, such as a gym and swimming pool.

The innovative approach to the organisation of office business services ensures privacy and carefree stays in clean environments without viruses, where businessmen are not forced to stay in the same spaces with other strangers but have their "safe bubble" - a safe zone which is important both during their travel at the time of the COVID-19 pandemic and also for further development of the post-COVID tourism of the future.

Changes in the lifestyle have encouraged an increased interest in mixed-use communities which offer simple access to the facilities and services on demand (Architecture digest 2021).

International hotel corporations, among which Marriott Corporation stands out, have recognised the developmental potential of branding of residential accommodation structures. In the English nomenclature, they are recognised as serviced apartments, selfcatering apartments, residences, structures which, in the Croatian Ordinance on classification, categorisation and specific standards of catering establishments from the Group Hotels, are categorised as aparthotels and tourist apartments. Due to the COVID19 pandemic, innovative organisational forms have been developed; thus, the Marriott Corporation is developing officetels, hotel offices which combine business activities and stays in remote destinations, enabling quality family holidays or affirming a special motivation, with a possibility of distant working services (Pinho and Marques 2021). 
ToSEE - Tourism in Southern and Eastern Europe, Vol. 6, pp. 247-268, 2021.

T. Floričić, N. Pavia: LINKAGE OF LEISURE WITH REMOTE WORK AND DIGITAL NOMADISM ...

Apart from residential, extended stay structures, other examples are also distinguished of an international hotel industry based on the classical hotel industry which affirms the trend of remote work and a specific offer in global tourism.

1. In New York, the smart hotel Yotel has been $100 \%$ created for digital nomads and business workers. The hotel offers several automated facilities: digital check-in machines, automated tools such as "Yobot" that leases out luggage lockers and the mobile concierge app "Shaggy". It also provides fast Wi-Fi, a floor for meetings and rooms designed as offices with smart beds stowing away into the wall to create a workspace during the day (Yotel Hotels 2021).

2. The Radisson hotel chain has developed a concept which is "the hotel office"; it consists of fully equipped, safe and private rooms for employees to enjoy a modern work area to be more productive than at home, while mixing personal space and working space results in lower productivity. The amenities offered in the rooms include all the informatics supplies you may need, such as HDMI cables and USB hubs, printing services, wireless keyboards and mice, high quality screens for video conferences and, most of all, free, fast and secure Wi-Fi (Radisson Hotels 2021).

3. Marriott Hotels provide a perfect work environment in destinations around the world. Marriott Bonvoy hotels have adapted in these particular times with the "work anywhere" concept. It allows workers to stay in the hotel for a day, overnight, or on family "workcations", thanks to their three different passes:

- Day pass - includes a 12-hour work time in a room with a functional desk, private bathroom and exposure to natural light, access to enhanced connectivity and Wi-Fi, along with printing, faxing and scanning devices.

- Stay pass - offers all the same amenities as the day pass; however, it allows guests to spend the night, check in early and check out late (6am to $6 \mathrm{pm}$ the next day). This pass allows guests to fully experience the hotel and its benefits, such as the spa, bar, restaurant and gym. Thanks to this pass, remote workers can truly work and rest without thinking about daily tasks and obligations.

- Play pass - can be referred to as a "workaction", where the aim is to allow office workers to bring along the whole family but still get their work done. There are supervised activities for kids and concierge services to assist with diverse work needs. Furthermore, there is access to semi-private workspaces and meeting rooms (Marriott Bonvoy 2021).

4. Hotel Wythe in Brooklyn - an example of the transformation of a business concept from "co-working" into "room working" content. The New York hotel, which was earlier encouraging freelancers and other creative people to use its public areas as a de facto workspace, changes the organisational concept, where guests are offered hotel rooms as their office spaces. The hotel partnered up with Industrious, a leading firm in the creation of flexible office spaces for companies like Lyft and Pfizer, for the rooms on the second floor to be turned into offices. They removed beds, hired office desks, put in plants so that a warmer atmosphere could be felt in the space and created an "offer for work concentration", with water and healthy snacks. "The rooms have a lot of 
ToSEE - Tourism in Southern and Eastern Europe, Vol. 6, pp. 247-268, 2021.

T. Floričić, N. Pavia: LINKAGE OF LEISURE WITH REMOTE WORK AND DIGITAL NOMADISM ...

natural light and high ceilings. By moving around standard furniture and beds a space is created, and it is perceived as a business potential for the creation of a new value", hotel comparative advantages are pointed out (Hotel White 2021).

5. Hotel Figueroa Work Perks Program - offers to its guests and to the local inhabitants a daily price of 129 dollars for the use of a room as an office, with facilities such as access to the swimming pool and fitness centre with an offer of free coffee and water, as well as unlimited use of a printer. The concept is intended for persons who, during a working day, need a quiet and professional environment with top service and hotel facilities in Los Angeles (Hotel Figueroa 2021).

6. Hyatt Hotels Worldwide - the Hyatt Company has formed a special service package "The Great Relocate", aimed at employers and individual guests who can work remotely, and which provides a unique way in which to see new parts of the world while working and living in the comfort of the Hyatt hotel. The offer is opened to the World of Hyatt members, but they can participate in achieving the status of an elite member (Hyatt Hotels Worldwide 2021).

\subsection{Promotion and distribution - Remote work facilities in the hospitality industry}

Given the evolving trend, Booking.com introduced a Work-Friendly badge on their website and a mobile app that establishments can gain if they have high quality service requirements, including great reviews and a cleanliness score of 8 or higher, as well as key amenities such as free Wi-Fi, dedicated workspaces and TVs. "By introducing the WorkFriendly Program we want to help travellers identify the home properties and meet their business requirements as well as help our accommodation partners to maximize their occupancy by attracting new types of travellers. Looking ahead, we will continue to look for new ways to surface relevant and key information to travellers on our platform and in turn support our partners" (booking.com 2020).

The functioning of the search engine on booking.com and the presentation of the special badge of Work Friendly Program is linked to the menu in which guests enter "I am travelling for work". In that choice, as search results, appear accommodation facilities with a special tag of Work Friendly Program, where their competitiveness is realised.

Considering future development, it could be said that not only booking.com will continue to search for new methods of improving the experience of travellers all around the world and solving the common issues, but also all other platforms, such as Airbnb. Companies will keep evolving and adapting faster to survive and regain power in the current environment in order to satisfy the demand. Among them, there is also a platform for holiday rentals Vrbo (2021), which promotes accommodation units for remote work as "a lovely and safe base for unhurried travellers and digital nomads", operating within the Expedia system.

Also, the importance of the social network Nomad List (2021) for digital nomads stands out, by means of which it is possible to share travel experiences and offer recommendations, and it is a set of information in one place about nomad destinations. The 
ToSEE - Tourism in Southern and Eastern Europe, Vol. 6, pp. 247-268, 2021.

T. Floričić, N. Pavia: LINKAGE OF LEISURE WITH REMOTE WORK AND DIGITAL NOMADISM ...

cost of subscription to this page is $\$ 79,99$ and it currently promotes the top five destinations with facilities for digital nomads: Lisbon, Mexico City, Taipei, Canngu (Bali) and Tenerife (Canary Islands). The following factors affect the positioning of the website destination: Internet speed, entertainment, cost of rental, safety, air quality, etc. (nomadlist.com 2021).

Remote work is on an exponential curve and is growing fast. With its growth, thousands of destinations, from tiny surf villages to cosmopolitan mega cities, are now competing to attract remote workers. Every second, Nomad List tracks the movement of tens of thousands of digital nomads to spot what the best places to live and work remotely right now are, and what the next spot might be. The example of Croatia could be presented as a successful digital nomadism practice. Namely, if the traveller earns $€ 2,230.00$ per month, he or she can stay for up to a year with an income tax exemption. Eventually, Croatia could attract up to 50,000 year-round remote workers. Indeed, following the collapse of tourism, which represents more than $20 \%$ of the GDP in Croatia, establishments are trying to renew themselves by attracting this new clientele. Besides the Nomad List website, there are also Nomad Pass and the Work Abroad Online Platform (2021).

\section{METHODOLOGY}

The methodology includes scientific analyses of the potential for affirmation of innovative accommodation concepts. The research design is as follows: metasearch was conducted focused on exploration of remote work tourism facilities including international and Croatian structures where the innovations related to remote work and digital nomadism were explored. The detected innovations pointed to further research including the SME hospitality sector, namely small hotels, agritourism and holiday rentals of Istria and Kvarner as the supply side of the hospitality industry. A questionnaire processed with statistic methodology was conducted. The specific sample of property owners and managers was chosen. The research explored their attitudes to reorganisation of facilities and property investment potential, as well their readiness to adapt their facilities to new requirements of demand related to remote work facilities and equipment in accommodation units. It also included the research of the readiness for introduction of technological innovations, namely facilities for remote work, including high speed Wi-Fi, laptops with installed cybersafe features, office equipment: printer, scanner, fax and business layout environment in the context of Post-COVID tourism. Methodology, supported by creative thinking techniques, impact the formation of conclusions, which points to new scientific knowledge.

Research was conducted in the northern Adriatic regions of Istria and Kvarner, the leading tourism regions of Croatia. The results were evaluated as valid and indicative and present a platform for generalisation at the national and international levels, aiming to present a contribution of the study. 
ToSEE - Tourism in Southern and Eastern Europe, Vol. 6, pp. 247-268, 2021.

T. Floričić, N. Pavia: LINKAGE OF LEISURE WITH REMOTE WORK AND DIGITAL NOMADISM ...

\section{EMPIRICAL RESEARCH ON HOSPITALITY PREPAREDNESS FOR DIGITAL NOMADS - THE CASE OF ISTRIA AND KVARNER}

Accommodation capacities, as an integral part of tourist offer, are an important factor which affects tourist experience. Small hotels, agritourism and holiday rentals form part of innovative accommodation offer, which enable guests to stay in a close, direct and family ambience. These are accommodation facilities which, according to their content, differentiate tourist offer. These accommodation facilities represent attractive accommodation capacities to different market segments.

Small family hotels and private accommodation facilities draw special attention, as they enable their guests to have direct contact with the locals and to familiarise themselves with the local culture and tradition. Holiday Rentals realise $50 \%$ of tourist overnights (Pinezić 2021), which points to the dominance of the structure over other types of tourist accommodation in the Republic of Croatia. Innovations in conceptualisation of the offer itself and the application of technological solutions contribute to the high quality of accommodation. Agritourism offers an attractive accommodation choice where, in addition to other services, users can directly participate in all agricultural activities.

The emergence of the COVID-19 pandemic has impacted changes in people's lives throughout the world. People have started experiencing a "new normality", which has normalised remote work and resulted in adoption of technologies which support virtual communication and remote working. Adaptation of accommodation offer to the new situation has also led to an increase in the tourist flows in the first quarter of 2021 in comparison to the previous year.

According to the data of the Croatian National Tourist Board, in the first quarter of 2021, an increase in tourist flows was recorded in comparison to the previous year. 592,352 tourist arrivals and 2,009,819 overnights were realised. The majority of overnights were recorded in commercial facilities. Most overnights were realised by hotels and privately/family-owned accommodation facilities. The largest number of overnights was realised in Istria (31.7\%), followed by Kvarner $(15.1 \%)$ and the Split-Dalmatia County $(12 \%)$. Although in the first quarter most counties recorded a decline in tourist traffic, the exception is the County of Istria, which recorded an increase.

\subsection{The sample and methodology description}

Anonymous research was conducted in April 2021 using survey questionnaires. The authors defined the targeted sample of small and medium-sized hotels, agritourism and holiday rental accommodation structures by exploring the official pages of the Tourism Board of Istria County and Kvarner County. Also, the database of the Kvarner family cluster website was researched, as well as the web directory of holiday rental providers of Istria and Kvarner regions. 
ToSEE - Tourism in Southern and Eastern Europe, Vol. 6, pp. 247-268, 2021.

T. Floričić, N. Pavia: LINKAGE OF LEISURE WITH REMOTE WORK AND DIGITAL NOMADISM ...

Table 1: Profile of researched accommodation offer providers

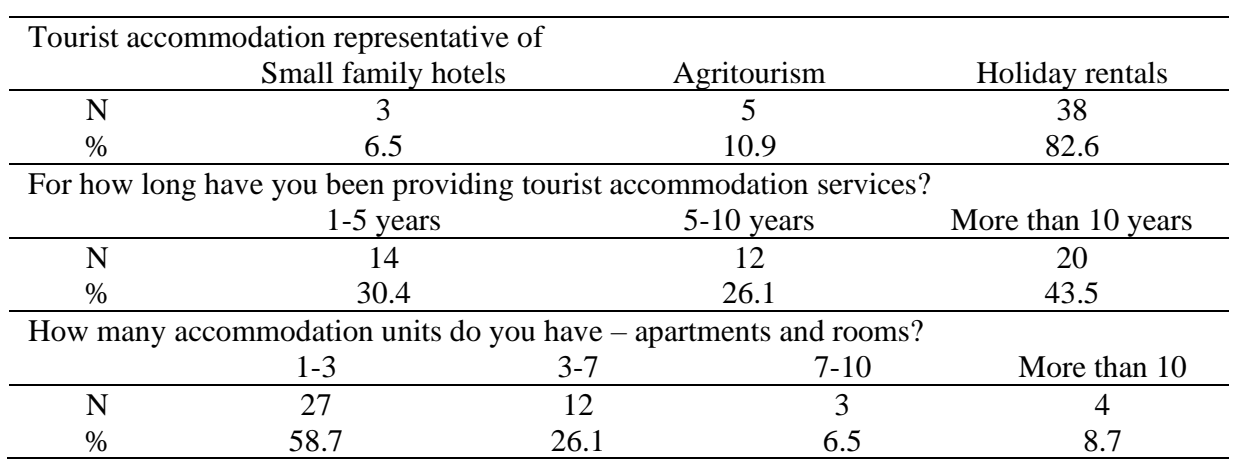

Source: Authors' research

The total number of invitations to participate numbered $65 ; 46$ replies were received, which represents a response rate of $70.76 \%$. The research sample was as follows: $6.5 \%$ small family hotels, $10.9 \%$ agritourism offer and predominantly $82.6 \%$ holiday rental accommodation facilities.

The data indicated that the examined sample was highly valid and reliable, given that over $69.6 \%$ of respondents have been in the business of provision of tourist accommodation for more than five years (43.5\% of them for over ten years). This implies a competency that resulted in experience in recognition of the market needs of the demand segment and involvement in the monitoring of global trends, since they affect the competitiveness aspects. A sound comprehension of the market in good and successful tourist seasons in the pre-pandemic period affects the decision-making strategies for overcoming of the crisis caused by the COVID-19 pandemic and the implementation of innovations.

\subsection{Research results and discussion}

Considering the number of accommodation structures, it is evidenced that $58.7 \%(\mathrm{~N}=27)$ offer accommodation in structures of between 1 and 3 accommodation units, $26.1 \%(\mathrm{~N}=12)$ dispose with between 3 and 7 accommodation units, $6.5 \%(\mathrm{~N}=3)$ have between 7 and 10 accommodation units and $8.7 \%(\mathrm{~N}=4)$ have more than 10 accommodation units. The data represents a profile of small and micro-entrepreneurships in the hospitality industry. Large, branded hotels and consortiums adopt trends easily and are carriers of innovations related with facility organisation. On the other hand, SME and micro-entrepreneurship due to their fragmentation, and, often also disunity and disloyal competition, lag behind with the implementation of innovations. A set of questions is therefore asked, by which the familiarity with the modern trend of digital nomadism, remote work and the concept of "Workspitality" are explored. 
ToSEE - Tourism in Southern and Eastern Europe, Vol. 6, pp. 247-268, 2021.

T. Floričić, N. Pavia: LINKAGE OF LEISURE WITH REMOTE WORK AND DIGITAL NOMADISM ...

Table 2: Familiarity with the concept of Digital nomadism and Remote work

\begin{tabular}{|c|c|c|c|c|}
\hline \multirow{2}{*}{ Question } & \multicolumn{2}{|c|}{ YES } & \multicolumn{2}{|c|}{$\mathrm{NO}$} \\
\hline & $\mathrm{N}$ & $\%$ & $\mathrm{~N}$ & $\%$ \\
\hline $\begin{array}{l}\text { Have you had any requests from Digital nomads and Remote } \\
\text { workers? }\end{array}$ & 9 & 19.6 & 37 & 80.4 \\
\hline $\begin{array}{l}\text { Are you familiar with the concept of Remote work and } \\
\text { Digital nomads? }\end{array}$ & 31 & 67.4 & 15 & 32.6 \\
\hline $\begin{array}{l}\text { Do you know what specific services and facilities Digital } \\
\text { nomads need? }\end{array}$ & 21 & 46.7 & 24 & 53.3 \\
\hline $\begin{array}{l}\text { Are you ready to invest in re-positioning of your } \\
\text { accommodation offer in order to enhance the technological } \\
\text { segment of your offer? }\end{array}$ & 30 & 65.2 & 16 & 34.8 \\
\hline
\end{tabular}

Source: Authors' research

The question which explores their realistic situation was asked, i.e. whether the respondents had to personally deal with queries related to remote work and digital nomadism. To the question on whether they had come across such demand, $80.4 \%$ of respondents gave negative answers $(\mathrm{N}=37)$, while $19.6 \%$ of them affirmed that specific queries related to stays in tourist accommodation with facilities which provide for remote work had been received.

The data points out that the respondents are mostly familiar with the concept of development of the offer for digital nomads and people who work remotely (remote workers) $-67.4 \%$. Although they are acquainted with the concept, not everyone is aware of a series of services which this specific accommodation product for digital nomads should provide, which is affirmed by a share of $46.7 \%$ of respondents. Enrichment of the offer and development of new products is always accompanied by involvement of a certain level of investment. Given the recognisability of the new demand segment which could affirm preand post-season tourist stays, the respondents were asked whether they were prepared to invest in the improvement of technological equipment. The respondents' answers indicate that $65.2 \%$ of them $(\mathrm{N}=30)$ were prepared for additional investment, which shows that they have recognised the need, showing their intention to accept it and affirm this new trend.

The third set of questions in the research was directed towards the current assessment of technological equipment and the contexts of implementation of the offer of remote work for the "Bleisure" and "Workspitality" segments and digital nomads.

Table 3: Evaluation of technological equipment of accommodation offer providers

\begin{tabular}{lcc}
\hline Grade the level of current technological equipment of your & $\mathrm{N}$ & $\%$ \\
accommodation offer & 36 & 78.2 \\
\hline Basic (Wi-Fi) & 5 & 10.9 \\
Sufficient (Wi-Fi, desk, printer, scanner) & 5 & 10.9 \\
High (Internet, computers, printer, scanner, fax, desk) & 46 & 100.0 \\
Total & & \\
\hline
\end{tabular}

Source: Authors' research 
ToSEE - Tourism in Southern and Eastern Europe, Vol. 6, pp. 247-268, 2021.

T. Floričić, N. Pavia: LINKAGE OF LEISURE WITH REMOTE WORK AND DIGITAL NOMADISM ...

To the statement: "In my accommodation facility I offer the following office services: fast Internet, Wi-Fi, computers, printers, scanners and desks", the locations were further examined to establish the presence of the stated services within the accommodation facility. Remote work facilities imply the presence of suitable equipment, i.e. laptops, connection of guests' computers with a central printer and scanner belonging to the facility, while some facilities offer the same set of equipment in each accommodation unit, which was also further researched. $67.4 \%$ of respondents $(\mathrm{N}=31)$ declared that they do not provide such services, $15.2 \%$ of them $(\mathrm{N}=7)$ offer them at reception level, while $17.4 \%$ of respondents $(\mathrm{N}=8)$ have organised services for office work in each accommodation unit. The aforestated corresponds to the indicator of the previous question and confirms the existence of a high level of technological equipment in accommodation facilities.

To the question which examines promotional channels and placement, by means of which the specific quality of the offer of remote work can be expressed, the respondents answered predominantly maybe/unsure $62.2 \%(\mathrm{~N}=28)$, negative $20 \%(\mathrm{~N}=9)$ and positive $17.8 \%$ $(\mathrm{N}=8)$. This specific question explored to what extent the offer stakeholders are aware of and open to innovative concepts. Namely, if the answers were predominantly yes or no, the position would have been clear. By offering the answer of maybe, the option was available to demonstrate an awareness of possible potentials but, at the same time, also a current unpreparedness to adopt and affirm them. The importance of education and the importance of the development of knowledge about the advantages of innovative concepts, therefore, is here recognised. Further to the previous question, the familiarity with the new label of the leading world portal booking.com. was explored. Namely, by accepting new trends, at the end of the year 2020, the portal developed a special label, "workfriendly badge", which the stakeholders of accommodation offer with organised facilities can apply and affirm through promotion and placement. To the presented question, the majority of respondents $(54.3 \%)$ were not aware of the new marketing tool at booking.com although they are promoted on the same portal. Also, in the light of consideration of adoption of the national marketing initiatives, $52.2 \%$ of respondents stated that they were familiar with the Croatian National Tourist Board's promotional campaign and the specific product entitled "Croatia, your new office". Given the percentage share, it is evident that this important campaign, which can considerably impact the extension of the tourist season in the sense of affirmation of the pre- and post-season periods, should intensify its visibility and become a platform for promotional campaigns which can be affirmed by accommodation offers through diversified promotional channels.

Table 4: Attitudes of accommodation offer providers towards the "workspitality" concept competitiveness

\begin{tabular}{|c|c|c|c|c|c|c|c|c|c|c|}
\hline $\begin{array}{l}\text { STATEMENT - } \\
\text { INTENSITY }\end{array}$ & & 1 & 2 & 3 & 4 & 5 & $\Sigma$ & Avg. & STDEV & Var-V \\
\hline \multirow{2}{*}{$\begin{array}{l}\text { Digital nomads and "Remote } \\
\text { work" (Workspitality) are an } \\
\text { important new demand } \\
\text { segment }\end{array}$} & $\mathrm{N}$ & 0 & 5 & 12 & 20 & 9 & 171 & 3.72 & 6.735 & 1.81 \\
\hline & $\%$ & 0.0 & 10.9 & 26.1 & 43.5 & 19.6 & 100.0 & & & \\
\hline \multirow{2}{*}{$\begin{array}{l}\text { Croatia is an important } \\
\text { destination for the } \\
\text { "Workspitality" segment }\end{array}$} & $\mathrm{N}$ & 1 & 3 & 12 & 12 & 18 & 181 & 3.93 & 6.306 & 1.60 \\
\hline & $\%$ & 2.2 & 6.5 & 26.1 & 26.1 & 39.1 & 100.0 & & & \\
\hline
\end{tabular}


ToSEE - Tourism in Southern and Eastern Europe, Vol. 6, pp. 247-268, 2021.

T. Floričić, N. Pavia: LINKAGE OF LEISURE WITH REMOTE WORK AND DIGITAL NOMADISM ...

Table 4 (continued)

\begin{tabular}{|c|c|c|c|c|c|c|c|c|c|c|}
\hline $\begin{array}{l}\text { STATEMENT - } \\
\text { INTENSITY }\end{array}$ & & 1 & 2 & 3 & 4 & 5 & $\Sigma$ & Avg. & STDEV & Var-V \\
\hline \multirow{2}{*}{$\begin{array}{l}\text { Special promotional and } \\
\text { distribution channels should be } \\
\text { used for the placement of this } \\
\text { specific offer }\end{array}$} & $\mathrm{N}$ & 0 & 2 & 20 & 16 & 8 & 168 & 3.65 & 7.756 & 2.12 \\
\hline & $\%$ & 0 & 4.3 & 43.5 & 34.8 & 17.4 & 100.0 & & & \\
\hline \multirow{2}{*}{$\begin{array}{l}\text { By investing in the } \\
\text { "Workspitality" offer it is } \\
\text { possible to achieve higher } \\
\text { prices }\end{array}$} & $\mathrm{N}$ & 0 & 3 & 18 & 19 & 6 & 166 & 3.61 & 7.833 & 2.17 \\
\hline & $\%$ & 0 & 6.5 & 39.1 & 41.3 & 13.0 & 100.0 & & & \\
\hline \multirow{2}{*}{$\begin{array}{l}\text { The "Workspitality" offer } \\
\text { ensures competitive advantage }\end{array}$} & $\mathrm{N}$ & 0 & 4 & 11 & 21 & 10 & 175 & 3.80 & 7.139 & 1.88 \\
\hline & $\%$ & 0 & 8.7 & 23.9 & 45.7 & 21.7 & 100.0 & & & \\
\hline \multirow{2}{*}{$\begin{array}{l}\text { State support through visas for } \\
\text { digital nomads contributes to } \\
\text { higher competitiveness }\end{array}$} & $\mathrm{N}$ & 1 & 4 & 14 & 15 & 12 & 171 & 3.72 & 5.636 & 1.52 \\
\hline & $\%$ & 2.2 & 8.7 & 30.4 & 32.6 & 26.1 & 100.0 & & & \\
\hline \multirow{2}{*}{$\begin{array}{l}\text { Post-Covid tourism will retain } \\
\text { the "Bleisure" characteristics }\end{array}$} & $\mathrm{N}$ & 0 & 3 & 15 & 21 & 7 & 170 & 3.70 & 7.756 & 2.10 \\
\hline & $\%$ & 0 & 6.5 & 32.6 & 45.7 & 15.2 & 100.0 & & & \\
\hline \multirow{3}{*}{$\begin{array}{l}\text { "Workspitality" will impact the } \\
\text { extension of the tourist season }\end{array}$} & $\mathrm{N}$ & 0 & 4 & 11 & 17 & 14 & 179 & 3.89 & 6.306 & 1.62 \\
\hline & $\%$ & 0 & 8.7 & 23.9 & 37.0 & 30.4 & 100.0 & & & \\
\hline & & 46 & 46 & 46 & 46 & 46 & & & & \\
\hline
\end{tabular}

Source: Authors' research

The following indicative answers are presented by an analysis of average grades.

The analysis is interesting of the complementarity of respondents' answers to the question about the importance of the "Workspitality" offer segment (3.72) and developmental potential of the future (3.70). This indicates that the respondents, in consideration of the identified trend, recognised its competitiveness and retention of its position in Post-Covid tourism. Equally, the importance of establishment of a visa system was graded, which will support the arrivals and work of digital nomads in Croatia (3.72). With this in place, from foreign tourists-visitors who travel and work (Workspitality), travellers, digital nomads, become the persons with a regulated stay status that surpasses tourist stays and who are, at the same time, users of tourist accommodation, by which hybridity of the concept is achieved.

In the assessment of statements, the statement "By investing in the "Workspitality" offer it is possible to achieve higher prices" was awarded the lowest grades (3.61). With regard to the concept innovativeness, which materialises in specific conditions of health uncertainty, and considering the fact that associated tourism is realised through innovative behavioural patterns, the lucrativeness of the investment will be evident in future years of stabilisation of the "new normal" tourism. As the respondents indicate their expectations that "Workspitality" will impact the extension of the tourist season (3.89) and award the highest grades to the statement that Croatia is becoming an important destination for this guest segment (3.93), expectations are evident of return of investment in the adaptation and formation of a tailor-made offer for digital nomads and remote work. 
ToSEE - Tourism in Southern and Eastern Europe, Vol. 6, pp. 247-268, 2021.

T. Floričić, N. Pavia: LINKAGE OF LEISURE WITH REMOTE WORK AND DIGITAL NOMADISM ...

Taking into consideration the connection between the high-graded statements which assess competitive advantage (3.80) and the tourist season extension (3.89) and valorisation of the profiled promotion and distribution channels for the "Workspitality" segment (3.65) and the lowest-graded potential of achievement of higher-level prices (3.61), it is evident that, for the tourist offer stakeholders, the length of the season and long-term competitiveness are important, whereas the pricing strategies are subject to elaboration in the future.

An analysis of the average grade and consideration of the dispersion measure standard deviation, show that average deviation from the average evaluation of the statements about the competitiveness of accommodation facilities ranges between 5.63 for the statement of evaluation of the new introduced visa regime for digital nomads in the Republic of Croatia, to 7.83 for the statement of evaluation of the possibility of achievement of a higher level of prices through investment in the offer for digital nomads.

Further, the variance of evaluation of the potential for the formation and investment in the offer for digital nomads is very weak, i.e. it points to a weak deviation and dispersion of samples in relation to the average. Ultimately, given the innovativeness and specificity of the trend which is increasingly entering the practice of modern hospitality business, the respondents were asked an open question, directed towards guests' proposals for the purposes of further evaluation and innovations of accommodation offers. The respondents stressed the importance of the programme packages for online meetings, cybersecurity settings for passwords and anonymous access to websites with implemented adblockers, smart locks and access control, tailor-made gastronomic offer in the facility according to the remote workers' and digital nomads' preferences (access to coffee, tea, water and high energy nibbles and snacks) but, above all, fast and reliable Internet throughout the accommodation facility. This was stated as being requested from Internet providers, as they have already purchased all the latest equipment, which cannot be functionally used due to the weak Internet provider signal.

Given the expectations supported by the theoretical determinants of the topic area, using Chi Square $\left(\mathrm{X}^{2}\right)$ test, the authors have tested opposingly expressed statements. Expectations of the potentials for extension of the season were tested, which is related directly to competitiveness and advantages of the use of specialised portals.

Table 5: Intensity of the importance of the "Workspitality" concept for the tourist season extension

\begin{tabular}{lcccc}
\hline & $\begin{array}{c}\text { Evaluate } \\
\text { importance -\% }\end{array}$ & Indifferent - $\%$ & $\begin{array}{c}\text { Evaluate as not } \\
\text { important } \%\end{array}$ & $\begin{array}{c}\text { Marginal } \\
\text { Row Totals }\end{array}$ \\
\hline Obtained frequency & 67.40 & 23.90 & 8.70 & 100 \\
$\begin{array}{l}\text { Expected frequency } \\
\begin{array}{l}\text { Marginal Column } \\
\text { Totals }\end{array}\end{array}$ & 40.00 & 40.00 & 20.00 & 100 \\
\hline $\begin{array}{l}\text { Chi-squared test: } \\
31.634\end{array}$ & Degrees of freedom: 2 & 63.90 & 28.70 & $\begin{array}{c}200 \text { (Grand } \\
\text { Total) }\end{array}$ \\
\hline
\end{tabular}

Source: Authors' research 
ToSEE - Tourism in Southern and Eastern Europe, Vol. 6, pp. 247-268, 2021.

T. Floričić, N. Pavia: LINKAGE OF LEISURE WITH REMOTE WORK AND DIGITAL NOMADISM ...

Table 6: Intensity of the importance of specialised promotion and distribution channels for the "Workspitality" offer

\begin{tabular}{lcccc}
\hline & $\begin{array}{c}\text { Evaluate } \\
\text { importance }-\%\end{array}$ & Indifferent - $\%$ & $\begin{array}{c}\text { Evaluate as not } \\
\text { important } \%\end{array}$ & $\begin{array}{c}\text { Marginal } \\
\text { Row Totals }\end{array}$ \\
\hline Obtained frequency & 52.20 & 43.50 & 4.30 & 100 \\
$\begin{array}{l}\text { Expected frequency } \\
\begin{array}{l}\text { Marginal Column } \\
\text { Totals }\end{array}\end{array}$ & 40.00 & 40.00 & 20.00 & 100 \\
\hline $\begin{array}{l}\text { Chi-squared } \\
\text { test:16.325 }\end{array}$ & Degrees of freedom: 2 & 200 (Grand \\
\end{tabular}

Source: Authors' research

The chi-squared test result data proves that providers of tourist accommodation offer believe that the "Workspitality" concept has an important impact on prolongation of the tourist season. The expected frequency which predicted respondents' positive opinions results in a more than $50 \%$ higher result $(27.4 \%)$ than expected and a large number of responses which negate the effect of the importance of remote work and the "Workspitality" concept is more than twice lower than the expected frequency; here, the chi-squared test result equals 31.634. Accordingly, the analysis of the importance of the specialised promotion and distribution channels, i.e. the effect of specialised portals for greater placement, points to an increased result in the realised frequency in relation to the expected one (12.2\%) and the accorded value in the evaluation of the indifferent respondents in the sense of perception of the obtained value is in relation to the expected one. This is supported by the chi-squared test result of 16.325 . The results of the test point to confirmation of the set research question.

Although, in general, bearers of the accommodation offer had not encountered digital nomadism and remote work, they are familiar with the development of this type of offer. They are aware of the need to adapt the offer to this new demand segment. Given that they have at their disposal only basic technological facilities, they are prepared to make additional investment in order to meet the requirements of the remote work segment and digital nomads within the workspitality concept. The bearers of the accommodation offer have recognised the importance of education and development of knowledge about the advantages of an innovative concept and placement of the offer through promotional channels. By the research, it has been confirmed that the workspitality concept can extend the tourist season through specialised portals with which targeted promotion and distribution are achieved, by various actions such as a new marketing tool "workfriendly badge", which was developed by the booking.com portal at the end of 2020, but there are also numerous promotional campaigns that reach this specific guest segment, nomad tourists and remote workers. 
ToSEE - Tourism in Southern and Eastern Europe, Vol. 6, pp. 247-268, 2021.

T. Floričić, N. Pavia: LINKAGE OF LEISURE WITH REMOTE WORK AND DIGITAL NOMADISM ...

\section{CONCLUSION}

Organisation of remote work facilities in accommodation units is a new way of innovating existing hospitality structure organisation and present an area where accommodation providers have found a niche for new competitiveness development. The remote working has only grown since the global pandemic, and it is predicted that it will also remain in post-pandemic tourism. It presents a win-win concept for everyone; employees can work from anywhere in the world and have more flexibility in their professional and personal lives, employers no longer need to pay for office space to accommodate all their teams and accommodation facilities can welcome new customers.

In addition, working remotely enables a higher level of personal health safety, a crucial factor in these uncertain times when physical distancing is an important factor of work productivity, crucially supported by high end Internet technologies: platforms for virtual meetings, webinars, various software, cybersecurity, as well as traditional hardware: computers, printers, scanners and fax devices. It is noted that additional new demand has emerged for secluded holiday rentals, agritourism and small family hotels. Facilities in smaller structures where privacy and isolation are offered present a competitive advantage as tourists do not prefer to socialise and mix with other unfamiliar people. The high share of holiday rentals, extended stay facilities and apartments present a platform for new solutions and innovation of tourism offer and present a switch impulse for new demand affirmation.

However, accommodation providers should pay attention when deciding to organise a "workspitality" accommodation facility, knowing that the tourists' preferences are of the greatest importance. Often, one of the reasons why people decide to work from a hotel is usually because they are tired of seeing the same landscape over and over again, they want to work, travel and spend time with family or because their Wi-Fi at home is too weak to work properly. That is why, when they look for accommodation that offers packaged services, they need to make sure that the Internet connection is broadband everywhere but also free, because some will offer Wi-Fi that will only work in the lobby, or not very well, making it difficult to work and make video calls. In addition, it should be considered that the room offered may not be comfortable enough to work, so special amenities should be offered: anatomic cushion for guests who suffer from back pain, a wireless mouse, a laptop stand or noise-cancelling headphones.

The research investigated the attitudes of tourist accommodation providers and their readiness for implementation of the "workspitality" concept in their service product organisation. A limitation of the study is recognised in the number and structure of the researched participants in the group of complementary accommodation facilities, although the replies pointed towards indicative remarks. They led to valuable recommendations that could present a scientific and applicative contribution of this paper:

- Importance of accommodation providers' education and awareness raising. This could be achieved through educative workshops and workbook materials organised by the national legislative Ministry and Tourism Board. 
ToSEE - Tourism in Southern and Eastern Europe, Vol. 6, pp. 247-268, 2021.

T. Floričić, N. Pavia: LINKAGE OF LEISURE WITH REMOTE WORK AND DIGITAL NOMADISM ...

- The importance and reachability of Internet distribution and promotion platforms should be valorised, and the accommodation providers should join special programmes and booking engines that enable digital nomad and workspitality bookings.

- Investments in accommodation facilities adaptation could return benefits on a shortterm basis as a workspitality concept, although producing lower prices in the pre- and post-seasons, could generate longer stays and higher occupancy and an extended tourism season, sometimes even whole year operations.

- Technologies and new concepts of online working will remain present in the postpandemic world and tourism. Tourist accommodation that offers new facilities, both for remote workers and accompanying persons and families, could benefit on a longterm basis. New trends create new demand preferences that should be explored in future research.

The research results in a scientific and practical understanding of the organisation and innovation of receptive offer, namely in accommodation offer in tourist destinations. The comprehension of a new, quality and secluded model of tourism could present a desirable path of destination development and the stakeholders involved should propose a new range of destination services which would provide a platform for future research. It should also include a future analysis of potential consumer preferences by which new services and facilities could be created, oriented towards new competitiveness.

\section{ACKNOWLEDGEMENTS}

This paper is a result of the scientific project "Tourism Development and Impact on Destination" supported by the Faculty of Economics and Tourism "Dr. Mijo Mirković", Juraj Dobrila University of Pula. Any opinions, findings, and conclusions or recommendations expressed in this paper are those of the author(s) and do not necessarily reflect the views of the Faculty of Economics and Tourism "Dr. Mijo Mirković" Pula.

The publishing of this paper is financially supported by Juraj Dobrila University of Pula, Project Tourism Development and Impact on Destination and by the authors personally.

The authors declare no conflict of interest.

\section{REFERENCES}

Andrés, J.P., Ladeiras, A.L., Culic, D., and Gini, M. (2019), For a New EU Integrated Tourism Policy: Europe - 27 Countries, One Destination, do Noroeste Peninsular, F.A. (ed.), EPICAH - Interreg Europe European Union, EU Regional Development Fund.

Bala, H.A. (2021), Designing eco cities with the understanding of digital nomads, Present and Future Paradigms of Cyberculture in the 21st Century, IGI Global, pp. 79-95. doi: 10.4018/978-1-52258024-9.ch005

Booking.com platform (2021), viewed 03 April 2021, https://partner.booking.com/en-us/help/propertypage/general-info/what-work-friendly-program

Cvent Company (n.d.), viewed 22 June 2021, https://www.cvent.com/

De Jong, L. and Lee, E. (2020), In the age of remote work hotel serve new purposes, viewed 04 November 2020, https://www.phocuswire.com/covid-created-new-role-for-hotels-citizenm

Digiday platform (2021), viewed 04 April 2021, https://digiday.com/marketing/remote-work-has-kickstarteda-hotel-subscription-living-movement/ 
ToSEE - Tourism in Southern and Eastern Europe, Vol. 6, pp. 247-268, 2021.

T. Floričić, N. Pavia: LINKAGE OF LEISURE WITH REMOTE WORK AND DIGITAL NOMADISM ...

Dinha, F. (2021), The hidden cost of remote work, Forbes magazine, USA, viewed 22 June 2021, https://www.forbes.com/sites/forbestechcouncil/2021/03/30/the-hidden-cost-of-remotework/?sh=762c62b26947

Electirc.ai (2020), How much does remote IT support cost? by Sheil, J., viewed 23 April 2021, https://www.electric.ai/blog/how-much-does-remote-it-support-cost

Gupta, R. (2021), Workspitality: a new trend that is helping hotels reinventing themselves, viewed 13 January 2021, https://www.4hoteliers.com/features/article/14112, www.bcgglobal

Hermann, I. and Cody, M. (2021), Digital nomadism: the nexus of remote working and travel mobility, Information, technology \& tourism, Vol. 22, No. 3. Special Issue: SI, pp. 329-334.

Hodari, J. (2021), Industrious, viewed 04 November 2020, https://www.architecturaldigest.com/story/covid19-hotel-working-spaces

Hotel Figueoroa, (n.d.), viewed 23 April 2021, https://www.hotelfigueroa.com/individual-workspace/

Hotel Wythe (n.d.), viewed 22 April 2021, https://www.wythehotel.com/

Hyatt Hotels - The world of Hyatt (n.d.), viewed 22 April 2021, https://world.hyatt.com/

JLL Company (2021a), viewed 04 November 2020, https://www.us.j1l.com/en/trends-and-insights/investor/whyflexible-space-is-appearing-in-office-investment-portfolios

JLL Company (2021b), viewed 04 November 2020, https://www.us.jll.com/en/trends-andinsights/research/covid19-impact-offices-will-find-a-new-purpose

Kachniewska, M. (2016), "Bleisure, business and leisure equilibrium in contemporary hotel chain", in Routledge handbook of hotel chain management, Routledge, pp.516-528.

Lichy, J. and McLeay, F. (2018), "Bleisure, Motivation and Typology", Journal of travel and tourism marketing, Vol. 35, No. 4, pp. 517-530.

Lubbe, B. (2020), "Business travel: a perspective paper, Tourism Review", Vol. 75, No. 1, pp. 113-116. https://doi.org/10.1108/TR-05-2019-0178

Marriot Bonvoy (n.d.), viewed 22 April 2021, https://workanywhere.marriott.com/play-pass

Marriott Bonvoy (n.d.), Day Pass, Play Pass $i$ Stay Pass, viewed 05 November 2020, https://www.4hoteliers.com/news/story/20842, Marriott International, Marriott International offers to work anywhere as an alternative to working from home.

Müller, A. (2016), The digital nomad: Buzzword or research category? Transnational Social Review, Vol. 6, No. 3, pp 344-348. https://doi.org/10.1080/21931674.2016.1229930

Neetbeez platform (2021), viewed 23 June 2021, https://netbeez.net/blog/remote-worker-tech-support-cost/

Nomad list platform (2021), viewed 22 April 2021, https://nomadlist.com/

Orel, M. (2020), "Life is better in flip flops, Digital nomads and their transformational travel to Thailand", International journal of culture tourism, Vol. 15, No. 1, pp. 3-9. https://doi.org/10.1108/IJCTHR12-2019-0229

Pinezić, N. (2021), Obiteljski smještaj je najveći investitor u turizmu i najveći kreator poslova, viewed 21 June 2021, https://hrturizam.hr/nedo-pinezic-obiteljski-smjestaj-je-najveci-investitor-u-turizmu-inajveci-kreator-poslova/

Pinho, M. and Marques, J. (2021), "The bleisure tourism trend and the potential for the business-leisure symbiosis in Porto", Journal of Convention \& Event Tourism, Vol. 22, No. 4, pp. 346-362. https://doi.org/10.1080/15470148.2021.1905575

Radisson Hotels (n.d.), viewed 22 April 2021, https://www.radissonhotels.com/en-us/

Richards, G. (2020a), Could digital nomads be an important growth segment for student travel? ICEF Monitor.

Richards ,G. (2020b), WYSE Organisation Webinar, viewed 20 February 2021, https:/www.wysetc.org/2020/05/wyse-webinar-the-impacts-of-covid-19-on-the-youth-travelindustry/

Richter, S. and Richter, A. (2020), Digital nomads, Business and Information system engineering, Vol. 62, No. 1, pp. 77-81.

The Croatian National Tourist Board (HTZ) (n.d.), Information on statistical tourist flow indicators - April 2021/January 2021

Thompson, B.J. (2018), "Digital nomads: employment in the online Gig Economy", Glogalism, Journal of Culture, politics and innovation, Vol. 1, pp. 1-26. https://doi.org/ 10.12893/gjcpi.2018.1.11

Vagena, A. (2021), "Digital nomads and tourism industry", Academia Letters, https://doi.org/10.20935/AL765

Von Zumbusch, J.S.H. and Lalicic, L. (2020), The role of co-living spaces in digital nomad's well-being. Information Technology \& Tourism, Vol. 22, No. 3, Special Issue, pp. 439-453 https://doi.org/10.1007/s40558-020-00182-2

Vrbo platform (2021), viewed 22 April 2021, https://www.vrbo.com/4753167ha?adultsCount=2\&arrival=2021 $08-18 \&$ departure $=2021-08-25$

Yotel Hotels (n.d.), viewed 22 April 2021, https://www.yotel.com/en/hotels/yotel-new-york 
ToSEE - Tourism in Southern and Eastern Europe, Vol. 6, pp. 247-268, 2021.

T. Floričić, N. Pavia: LINKAGE OF LEISURE WITH REMOTE WORK AND DIGITAL NOMADISM ...

Zoom Communication platform (n.d.), viewed 08 April 2021, https://zoom.us/docs/en-us/hybridworkforce.html?zcid $=4760 \&$ creative $=520797851240 \&$ keyword $=$ remote $\% 20$ work $\&$ matchtype $=p$ \&network $=$ g\&device $=c \&$ gclid $=C j w K C A j w v \_i E B h A S E i w A R o e m v F 9 a q B m h W d m I I L 7 f N 8 Q o o i l 3$ znUS3YBvRYhW9IrRlpuUrbKsSG4DExoCcLcQAvD_BwE

Floričić Tamara, PhD, Assistant Professor

Juraj Dobrila University of Pula, Faculty of Economics and Tourism "Dr. Mijo Mirković"

Preradovićeva 1,52100 Pula, Croatia

++385-38-55237700

tfloricic@unipu.hr

Nadia Pavia, PhD, Full Professor Tenured

University of Rijeka, Faculty of Tourism and Hospitality Management

Primorska 46, 51410 Opatija, Croatia

++385-51-294-190

nadiap@fthm.hr 